\title{
Assessment of methane emissions from Danish livestock production practices using a tracer gas dispersion method
}

Vechi, Nathalia dos Reis; Delre, Antonio; Scheutz, Charlotte

Publication date:

2020

Document Version

Publisher's PDF, also known as Version of record

Link back to DTU Orbit

Citation (APA):

Vechi, N. D. R., Delre, A., \& Scheutz, C. (2020). Assessment of methane emissions from Danish livestock production practices using a tracer gas dispersion method. Abstract from EGU General Assembly 2020.

\section{General rights}

Copyright and moral rights for the publications made accessible in the public portal are retained by the authors and/or other copyright owners and it is a condition of accessing publications that users recognise and abide by the legal requirements associated with these rights.

- Users may download and print one copy of any publication from the public portal for the purpose of private study or research.

- You may not further distribute the material or use it for any profit-making activity or commercial gain

- You may freely distribute the URL identifying the publication in the public portal 
EGU2020-20405

https://doi.org/10.5194/egusphere-egu2020-20405

EGU General Assembly 2020

(c) Author(s) 2020. This work is distributed under

the Creative Commons Attribution 4.0 License.

\title{
Assessment of methane emissions from Danish livestock production practices using a tracer gas dispersion method
}

\author{
Nathalia dos Reis Vechi, Antonio Delre, and Charlotte Scheutz \\ Technical University of Denmark, Department of Environmental Engineering, Denmark (navei@env.dtu.dk)
}

One of the largest methane anthropogenic sources worldwide is livestock production. In Denmark, this contribution reached $81.1 \%$ of total anthropogenic methane, divided into both enteric fermentation and manure management emissions (Nielsen et al., 2019). Numerous factors can influence methane emissions from livestock production. The development of strategies to measure and monitor this anthropogenic activity allows the identification of efficient mitigation actions. The dynamic tracer gas dispersion method (TDM) is a ground-based remote sensing method, which combines a controlled release of tracer gas from the target source with concentration measurements downwind of the same source. TDM has been compared to other remote sensing techniques and widely applied for methane quantification from many facilities (Samuelsson et al., 2018). Previous studies found that this method is very likely to reached up to only $20 \%$ of error (Fredenslund et al., 2019). For livestock methane quantification, TDM has been used before releasing a strong greenhouse gas $\left(\mathrm{SF}_{6}\right)$ with mostly stationary point sampling setup. The aim is to verify the suitability of the method for these facilities and identify the differences between farming approaches. Furthermore, the comparison of the measured emissions with inventory estimation could show the accuracy of the later.

This study uses acetylene as tracer gas and measurements performed with a fast responding and highly sensitive gas analyzer by Picarro. On this project, emissions from six livestock facilities (dairy cows and swine production) were investigated along one year.

Dairy farms were the largest methane emitters per head (Around $40 \mathrm{gCH}_{4} / \mathrm{head} / \mathrm{h}$ ). Results show that management practices might cause different methane emissions from dairy farms. Similar result was observed analyzing emissions from pig facilities (Around $6 \mathrm{gCH}_{4} / \mathrm{head} / \mathrm{h}$ ), with an influence of animal life stage. The sow's farm had the highest methane emission factor when compared to fattening pigs, while manure acidification treatment might have a positive impact on reducing methane emission.

The successful application in this study of the TDM showed that this method is a valuable tool to support Danish farming strategies to meet ambitious GHG emission reduction targets. 
Fredenslund, A. M., Rees-White, T. C., Beaven, R. P., Delre, A., Finlayson, A., Helmore, J., ... Scheutz, C. (2019). Validation and error assessment of the mobile tracer gas dispersion method for measurement of fugitive emissions from area sources. Waste Management, 83, 68-78.

Nielsen, O.-K., Plejdrup, M. S., Winther, M., Nielsen, M., Gyldenkærne, S., Mikkelsen, M. H., ... Hansen, M. G. (2019). Denmark's National Inventory Report 2019 (Emission I).

Samuelsson, J., Delre, A., Tumlin, S., Hadi, S., Offerle, B., \& Scheutz, C. (2018). Optical technologies applied alongside on-site and remote approaches for climate gas emission quantification at a wastewater treatment plant. Water Research, 131, 299-309. 